\title{
On the Shift of Parts of Speech in Prepositional Meaning in English-Vietnamese Translation
}

\author{
Phat Dinh Dac ${ }^{1 *}$
}

${ }^{1}$ Saigon University, Ho Chi Minh City, Vietnam

"Correspondence: Phat Dinh Dac, Saigon University, Vietnam. E-mail: dinhdacphat98@ yahoo.com.vn: https://orcid.org/0000-0003-1388-3992

doi)https://doi.org/10.54855/acoj.2213110

\section{Abstract}

Exploring the shift in meanings of translating prepositions from English to Vietnamese, the study, besides analyzing the cases of the changes in meanings of prepositions, aims to discuss a general variety of meanings of English prepositions. The methods of analysis and synthesis of theories from the available data on prepositions as well as the methods of classifying and systematizing prepositions were applied to English-Vietnamese translation. From the collected data, this study has revealed 6 cases of the shift in meanings of prepositions and the characteristics of multiple meanings of prepositions. In the course of translation, contextual meanings are used in order to convey the meanings appropriately in the Vietnamese style. The research paper can make some contribution to the teaching of translation and make it a reference material for English learners.

Keywords: prepositions, translation, English, Vietnamese, the shift in meanings, multimeaning

\section{Introduction}

Prepositions in English have some similarities with those in Vietnamese. However, there are cases where prepositions are used differently between two languages, especially in different contexts, leading to different meanings in translation. The phenomenon of changing the meaning of prepositions when translating from English to Vietnamese sometimes confuses translators due to the habit of translating from Vietnamese to English in a single sense, making language expressions unnatural and difficult to understand. Flexibility when translating prepositions will help translators convey the content of the translation accurately, avoiding translation errors about prepositions.

Therefore, the correct use of prepositions is very important because people use them to indicate the action and details of what people are going to convey. Understanding prepositions not only helps to use English naturally but also helps to translate documents and texts correctly (The Key to English Prepositions 1, Collier-Macmillan International, 1964). However, many learners in Vietnam find it difficult to translate prepositions correctly in many different contexts.

In addition, English learners often tend to translate languages according to their mother tongue. Therefore, they need to realize that there is no such thing as translating an exact preposition in 
a single sense from English to Vietnamese and vice versa. We know that sometimes we have to add or subtract prepositions when translating a sentence from one language to another. Moreover, Vietnamese prepositions would have some meanings similar to English, so the translation of prepositions needs to be carefully guided for learners so that they can recognize this problem and know the appropriate prepositions to use in different situations to avoid errors when using.

In short, to use English prepositions when translating from English to Vietnamese correctly, learners need to know the phenomena of prepositional meaning change when translating from English to Vietnamese, as well as the phenomenon of multiple meanings of a preposition in different contexts. There are no universal rules for using prepositions, and learners should not directly translate prepositions into their native language since prepositions are used differently in different languages. As mentioned above, it is very necessary to study the phenomenon of prepositions when translating from English to Vietnamese.

\section{Literature review}

\section{a) Domestic research}

In Vietnam, there are topics related to prepositions such as:

- Tran, V. D. (1997). Cách dùng giới tù̀ Anh ngũu, Nhà Xuất bản Thành phố Hồ Chí Minh.

- Tran, Q. H. (2001). Nghiên cúu giới tù định vị theo huớng ngũ dụng trên cứ liệu tiếng Anh và tiếng Việt, Master Thesis of Science in Literature, University of Social Sciences and Humanities - Hanoi National University.

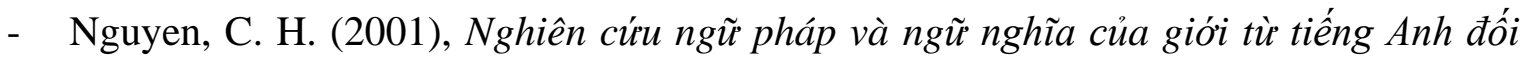
chiếu với tiếng Việt, Doctoral Thesis, University of Social Sciences and Humanities Hanoi National University.

- Nguyen, T. T. H. (2020), Giới tù định vị tiếng Anh (at, in, on) và các đơn vị tương đưong trong tiếng Việt, Doctoral Thesis, University of Social Sciences and Humanities - Ho Chi Minh City National University.

\section{b) International research}

In countries around the world, there are materials related to prepositions such as:

- Collier-Macmillan International (1964) - The Key to English Prepositions 1, CollierMacmillan Limited, London, v.

- Seth Lindstromberg (2010) - English Prepositions Explained, Amsterdam: John Benjamins Publishing Company.

- $\quad$ Tom Hutch (2015) - 150 Everyday Uses of Prepositions in English, Learning Express.

- Jean Yates (2020) - Barron's ESL Proficiency Series: Prepositions, Kaplan, Inc., Barron's Educational Series. 
Researches and works related to prepositions mentioned above, whether in the domestic or foreign scope, have partly provided useful content and materials for students who want to learn about prepositions. As Tran (1997) showed that prepositions could follow verbs, adjectives, and nouns and would perform different functions, and at the same time shows the general pattern of prepositional meaning in English - Vietnamese translation. The Ph.D. thesis of Tran (2001) identified the pragmatic factors affecting the choice of locative prepositions. The Ph.D. thesis of Nguyen (2001) has shown the comparison of English and Vietnamese prepositions in terms of grammatical characteristics so that it can be applied to the analysis of errors of Vietnamese people when learning English prepositions. The Ph.D. thesis of Nguyen (2020) analyzed the phenomenon of multi-meaning of the English preposition "in" from the perspective of cognitive linguistics. The Ph.D. thesis of Nguyen (2020) showed the locating prepositions of "at, in, on" in English and equivalent meanings in Vietnamese in terms of grammar and semantics.

There are also documents and books that focus on the use of prepositions. Collier-Macmillan International (1964) - The Key to English Prepositions 1 also classified each group of prepositions used for different functions such as time, position, measure, number, etc. Thereby, each preposition, when going with nouns, will give different meanings. Seth Lindstromberg (2010) - English Prepositions Explained classified prepositions used in different meanings and functions in each specific case. At the same time, he also grouped prepositions that have the same meaning but will be different in each context. Tom Hutch (2015) - 150 Everyday Uses of Prepositions in English listed common prepositions used in everyday life and Jean Yates (2020) - Barron's ESL Proficiency Series: Prepositions listed each prepositions' meaning in contexts.

However, the above studies and documents are only generalizations, or they provide research results in certain aspects. There has not been any in-depth research on the phenomenon of prepositions in English to Vietnamese translation. In other words, there have not been any deep studies of how an English preposition will have different meanings in different contexts. Therefore, this study would analyze the phenomenon of transfer meaning between EnglishVietnamese prepositions with the desire to clarify the phenomenon of meaning transference of prepositions in sentences, one of the difficulties for English learners.

\subsection{Research Questions}

To fulfil the purpose of the study, the survey was to answer the following research questions:

a. How many transitions of prepositions are there when translating from English to Vietnamese?

b. Does the phenomenon of polysemy appear in the same preposition in addition to its original meaning in different contexts? 


\section{Methods}

\subsection{Data}

Researching prepositions in English (focusing on common prepositions that learners often think of first when asked about prepositions in English such as at, in, on, for, from, to, above, before, without, and so on) and comparing equivalent meanings in Vietnamese such as $\mathscr{o}$, trong, trên, cho, tùt, tới, trên, trước, mà không, ...)

\subsection{Design of the Study}

The study used the following methods. Firstly, the writer uses the comparative and contrastive method to research the similarities and differences between English and Vietnamese prepositions. Secondly, the writer uses the analyzing and synthesizing theory method to study documents about prepositions in English and look for examples of sentences using prepositions in texts to serve as illustrative examples. Finally, the writer uses the classification and systematization of theory method to distinguish each phenomenon of prepositional meaning transition when translating from English to Vietnamese.

This study would examine and analyze each phenomenon of prepositional meaning change when translating from English to Vietnamese. In translated sentences, the author will try to convey the exact meaning of the sentences in certain contexts.

\subsection{Data collection \& analysis}

The study focused on English-Vietnamese prepositions and the phenomenon of prepositional meaning change when translating from English to Vietnamese. Data and examples were taken from 5 sources, including 150 Everyday Uses of Prepositions in English by Tom Hutch, Barron's ESL Proficiency Series: Prepositions by Jean Yates, Cách dùng giới tù Anh ngũu by Tran Van Dien, English Prepositions Explained by Seth Lindstromberg and The Key to English Preopistions 1 by Collier-Macmillan International. All documents are original, and the author would select a few examples that use prepositions used in everyday language to show the difference in meaning in each language when translated.

\section{Results}

\subsection{Prepositions are present in English but not in Vietnamese}

Take the verb wait, in English, if we use this verb with the purpose of waiting for someone, it would be:

(1) I will wait for you till 5 o'clock. (Tran, 1997, 10)

(2) I have waited for you from the morning till now. (Tran, 1997, 13)

However, if translated into Vietnamese according to the Vietnamese speaking style, the two sentences above will give the following meaning: 
(1) Tôi sẽ chò̀ ban tới 5 giò̀.

(2) Tôi đã chờ ban tù sáng cho tới bây giò.

Next is the verb arrive, in English if we use this verb to talk about going somewhere, it will be:

(3) He arrives at Dallat. (Tran, 1997, 12)

(4) We arrive in Saigon. (Tran, 1997, 22)

When translated into Vietnamese according to the Vietnamese style, the two sentences above will give the following meaning:

(3) Anh ta tới Đà Lạt.

(4) Chúng tôi tới Saigon.

We will not translate that:

(3) Anh ta tóì ö Đà Lạt.

(4) Chúng tôi tới trong Saigon.

\subsection{Prepositions are not present in English but are present in Vietnamese.}

Take the case of the verb contact, in English, if we use this verb for the purpose of communicating between people, it would be:

(5) They contacted me about my trip. (Yates, 2020, 20)

(6) You can contact him by e-mail. (Yates, 2020, 48)

However, if translated into Vietnamese according to the Vietnamese speaking style, the two sentences above will give the following meaning:

(5) Ho liên lac với tôi về chuyến đi.

(6) Bạn có thể liên lac với anh ta qua địa chỉ e-mail.

Take another case of the verb enter, in English, we use this verb to talk about where to go inside, then we will use:

(7) When the president entered the room, everyone stood up. (Yates, 2020, 215)

(8) He enters my room. (Tran, 1997, 12)

When translated into Vietnamese, the two sentences above will give the following meaning:

(7) Khi chủ tịch vào trong căn phòng, mọi người đều đứng dậy.

(8) Anh ta vào trong phòng tôi.

The most common causes of this change of meaning are often in the form of sentences of ditransitive verbs:

S + ditransitive verbs + indirect object + direct object

(9) She bought him a present.

(10) Cong Phuong passed Quang Hai the ball. 
With the above sentences, we will often translate as:

(9) Cô ta mua cho anh ấy một món quà.

(10) Công Phượng chuyền banh cho Quang Hải.

\subsection{Prepositions are present in both English and Vietnamese}

Take the verb disagree, in English, if we use this verb for the purpose of expressing an opinion, it would be:

(11) Whatever I say, she always disagrees with me. (Hutch, 2015, 43)

(12) ... I sort of disagreeing with them. (Hutch, 2015, 57)

If translated into Vietnamese according to the Vietnamese speaking style, the two sentences above will give the following meaning:

(11) Tôi có nói gì, cô ấy luôn luôn không đồng ý với tôi.

(12) ... tôi kiểu nhu không đồng tình với họ.

Take the verb phrase talk about, in English, when we use it to express what we mean about something, we will use:

(13) He often talks about his job. (Yates, 2020, 19)

(14) He talked about you. (Tran, 1997, 15)

If translated according to the Vietnamese style, we would say:

(13) Anh ta thường nói vì công việc của mình.

(14) Anh ta đã nói về bạn.

4.4 Prepositions are present in both English and Vietnamese but different prepositions are used

Take the phrase be famous for, in English, we use to refer to a thing/situation that is famous, then we will have the following sentences:

(15) Da Lat is a city famous for its climate. (Tran, 1997, 145)

(16) She is famous for giving great parties. (Yates, 2020, 91)

If translated according to the Vietnamese style, we would say:

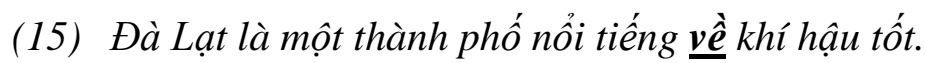

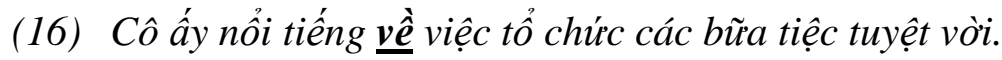

When translating into Vietnamese, English will still use the preposition for. Meanwhile, the Vietnamese will use the preposition about $(\boldsymbol{v} \hat{\boldsymbol{e}})$. Therefore, we will use the wrong preposition if translating in normal Vietnamese:

(15) Da Lat is a city famous for its climate.

(16) She is famous about giving great parties.

Next is the verb remind, in English, if we use it to talk about reminding someone of/about something, we will use it with the preposition of according to the structure: 


\section{to remind somebody of someone/something}

(17) She reminds me of my sister. (Yates, 2020, 260)

(18) The purple color reminds me of her. (Tran, 1997, 92)

In this case, when translating into Vietnamese, we will translate it as:

(17) Cô ấy làm tôi nhớ tới/về chị gái của tôi.

(18) Màu tím làm tôi nhớ tới/về cô ấy.

Therefore, we will use the wrong preposition if translating in normal Vietnamese:

(17) She reminds me tolabout my sister.

(18)The purple color reminds me tolabout her.

\subsection{Prepositions are not present in both English and Vietnamese}

In this case of translation, in English and Vietnamese sentences, they both describe common actions.

(19) I am awaiting your visit with pleasure. (Yates, 2020, 199)

(20) I was inspired by that film to become a fireman. (Hutch, 2015, 2020)

(21) After reading this article three times, I still don't understand it. (Yates, 2020, 30)

Translated into Vietnamese, the above sentences will give the meaning:

(19) Tôi đang trông đơi chyến thăm của bạn với niềm vui mùng.

(20) Bộ phim truyền cảm hứng cho tôi để trở thành lính cưu hỏa.

(21) Sau khi đoc bài báo này ba lần, tôi vẫn không hiểu nó.

With become and read, there will never be a preposition followed if translated into Vietnamese:

(20) I waspired by that film to become into a fireman.

(21) After reading about this article three times, I still don't understand it.

\subsection{Prepositions are present in English, when translated into Vietnamese, they act as conjunctions or verbs}

In some cases, when translating an English to Vietnamese preposition in a sentence, we will see that the meaning of the preposition now has the meaning of conjunction or verb. Examples of the following sentences with the preposition with:

a) With in the meaning of conjunction:

(22) With (In case of) problems of this sort, you have got to think in terms of five- or ten-year periods. (Lindstromberg, 2010, 219)

(22) Trong truò̀ng hơp của nhũng vấn thuộc loại này, bạn phải nghĩ vê khoảng thời gian năm hoặc mười năm

(23) The flower is wet with (because of) dew. (Tran, 1997, 16) 
(23) Nhĩng bông hoa bị wớt bởi sương sớm.

(24) The girl's face is wet with (because of) tears. (Yates, 2020, 224)

(24) Khuôn mặt của cô gái uoót vì nuớc mắt.

(25) I love him with (despite) all his faults. (Yates, 2020, 225)

(25) Tôi yêu anh ấy bất chấp tất cả nhũng lỗi lầm của ảnh.

(26) With (Despite) all her problems, she is quite serene. (Yates, 2020, 225)

(26) Bất chấp mọi vấn đề của mình, cô ấy vẫn khá thanh thản.

b) With in the meaning of verb:

(27) The man with (who has) brown eyes is my father. (Tran, 1997, 15)

(27) Người đàn ông $\underline{\text { có }}$ đôi mắt màu nâu là cha tôi.

(28) I am with (agree) you on that point. (Tran, 1997, 15)

(28) Tôi đồng ý với bạn ở điểm đó.

(29) I have an article with (that contains) pictures for my presentation.

(30) (Yates, 2020, 219)

(29) Tôi có một bài báo chứa nhũ̃ng búc ảnh cho bài thuyết trình của mình.

Another case of the preposition against, in the meaning of verb:

(30) They held the mirror against (touch) the wall. (Yates, 2020, 33)

(30) Ho giũ gưong dưa vào tưòng.

(31) He is always against (disagree) me. (Tran, 1997, 16)

(31) Anh ta luôn chống đối tôi. (Tran, 1997, 16)

When placed in different contexts, the original meaning will be lost and give different meanings similar to Vietnamese. This phenomenon occurs due to elements of Vietnamese culture. At this point, the meaning of the two sides will no longer be equivalent to each other in the original sense. There will be many other meanings in the same preposition, and the study will only generalize to show that the phenomenon of multiple meanings of prepositions in the context is present.

Now, the study will focus on the preposition on, one of the most commonly used prepositions in both English and Vietnamese prepositions to show the phenomenon of multi-meaning of prepositions when translating from English to Vietnamese.

(1) on, in its original sense, is often translated by Vietnamese as trên:

(32) The newspaper is on the table. (Yates, 2020, 149)

(32) Tò báo ở trên bàn.

(33) There are a lot of movies on television. (Yates, 2020, 159)

(33) Có rất nhiều bộ phim trên TV.

(2) on can be translated as $\boldsymbol{o}^{3}$ in Vietnamese:

(34) Please open your book on page one (Yates, 2020, 150)

(34) Hãy mở sách của bạn ra ơ trang môtt.

(35) I live on the fourth floor ... (Tran, 1997, 23) 


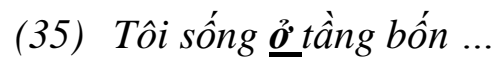

(36) I am with you on that point. (Tran, 1997, 15)

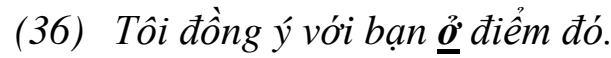

(3) on can be translated as vào in Vietnamese:

(37) Come and see me on Mondays. (Tran, 1997, 10)

(37) Hãy đến và gặp tôi vào thứ hai.

(38) He vistis twice a month on weekends. (Yates, 2020, 153)

(38) Anh ta viếng thăm hai lần một tháng vào các ngày cuối tuần.

(4) on can be translated as bằng in Vietnamese:

(39) He came over on his bike. (Yates, 2020,151)

(39) Anh ta ghé chơ bằng xe đẹp.

(40) George usually goes to work on the bus. (Macmilland, 1968, 15)

(40) George thuờng đi làm bằng xe buýt ...

(41) That car runs on diesel fuel. (Yates, 2020, 153)

(41) Chiếc xe hoi đó chay bằng dầu đi-e-zel.

(42) He wrote his paper on the computer. (Yates, 2020, 154)

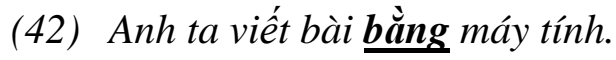

(5) on can be translated as về in Vietnamese:

(43) He gave me a lecture on science. (Tran, 1997, 15)

(43) Anh ấy giảng cho tôi $\underline{\underline{\mathbf{v}}}$ khoa hoc.

(44) We have a good book on gardening. (Yates, 2020, 155)

(44) Chúng tôi có một cuốn sách về̀ làm vuoòn.

(6) on can be translated as bên in Vietnamese:

(45) The porch is on the side of the house. (Yates, 2020,150)

(45) Mái hiên bên hông nhà.

(46) Did you notice the twin oak trees on the left hand side of the path? (Lindstromberg, 2010: 58)

(46) Bạn có để ý thấy đôi cây sồi bên tay trái của lối đi không?

(7) on can be translated as đối diện in Vietnamese:

(47) Their house is on the beach. (Yates, 2020, 150)

(47) Nhà của họ đối diện bãi biển.

(48) Both of these campgrounds are right on the ocean. (Lindstrormberg, 2010, 52)

(48) Cả hai khu cắm trại đều đấi diện ngay bãi biển.

(8) on can be translated as trong in Vietnamese:

(49) She is on the basketball team ... (Yates, 2020, 156)

(49) Cô ta trong đội bóng rổ... 
(9) on can be translated as lên in Vietnamese:

(50) She poured water on the plant. (Yates, 2020, 151)

(51) Cô ta tưới nước lên cái cây.

(52) He sprinkled salt on the meat. (Yates, 2020, 151)

(51) Anh ấy rắc muối lên miếng thịt.

(10) on can be translated as $\boldsymbol{k h i}$ in Vietnamese:

(52) She fainted on hearing the news. (Yates, 2020, 159)

(52) Cô ấy ngất khi nghe thông tin.

(53) On hearing the victory, people were transported with joy. (Tran, 1997, 180)

(53) Khi nghe tin chiến thắng, dân chúng xiết nỗi vui mùng.

(11) on can be translated as với in Vietnamese:

(54) The teacher is much too easy on the boys. (Yates, 2020, 160)

(54) Người giáo viên quá dễ dãi với nhũng hoc sinh nam.

(55) I think I was too rough on her yesterday. (Yates, 2020, 160)

(55) Tôi nghĩ tôi đã quá khắt khe với cô ta ngày hôm qua.

In addition to the above cases, the preposition on has other meanings in English expressions but does not carry the prepositional meaning when translated into Vietnamese. In this case, the translator will use Vietnamese expressions with similar meanings to express the meaning of on in the sentence. For example:

(56) They were on the road for two days during their trip. (Macmillan, 1964, 3)

(56) Họ đã đi đượ 2 ngày trong suốt chuyến đi.

(57) The light's on. (Lindstromberg, 2010, 65)

(57) Đèn đang bât

(58) The meeting's on. (vs off) (Lindstromberg, 2010, 65)

(58) Cuộc hop đang diễn ra.

(59) He is always on hand to help us. (Yates, 2020, 158)

(59) Anh ta luôn có mă để giúp chúng tôi.

(60) She is on a diet. ( Yates, 2020, 158)

(60) Cô ta đang ăn kiêng.

Through analyzing the preposition on in the above contexts, the author has pointed out $\mathbf{1 1}$ different meanings of the preposition "on" when placed in different contexts and the exception when it is a fixed phrase, resulting in similar meanings to Vietnamese when translated. 


\section{Conclusion and Discussion}

\section{Summarising}

The research has answered two questions raised by referencing documents on English and Vietnamese prepositions as a basis for research and surveying cases of prepositional transitions when translating from English to Vietnamese. Specifically, how many phenomena will occur when we translate English prepositions into Vietnamese and whether an English preposition can have many meanings other than the original meaning when placed in different contexts.

The study shows that there are $\mathbf{6}$ cases of transition of prepositions when translating from English to Vietnamese. Cases showing the similarities and differences of prepositions in each different language will have different usage, thereby drawing the conclusion that prepositions are arbitrary and do not have a prepositional using method. There will be cases where prepositions are present in both English and Vietnamese, and they have the same meaning when translated. There will be cases where prepositions are added or omitted, or both have the same meaning, but the preposition is used differently, and there are cases where there are no prepositions in sentences to describe actions.

The study also shows that in translation, learners or translators need to look closely at the phenomena of translation in order to be able to convey the correct meaning and use the correct prepositions. Moreover, the study also shows that when considering the cultural factor of the language to be translated, it will give different meanings in one preposition. To clarify, the preposition on can be translated in many meanings similar to other prepositions in Vietnamese and other expressions in addition to the original meaning trên, including other 10 meanings: ở, vào, bằng, về, bên, đối diện, trong, lên, khi, với.

The findings in this paper provide the basis for people to see that prepositions are one of the important aspects of English. Understanding and using correct prepositions will help us express our ideas through language and express it naturally. According to Tran (1997), "learning the form and meaning of prepositions is not enough. What matters is learning how to use prepositions in different situations." The study also shows that the proficient use of English prepositions does not have a uniform rule, but it takes practice and habits to become proficient. Prepositions are diverse and always change meaning when placed in different contexts. Therefore, there is no method of using prepositions.

According to Nguyen (2001), in both English and Vietnamese, linguists classify prepositions into functional words, linking words, empty words, etc. Prepositions have an important position in the word system. Type, it has the ability to connect, showing the relationship between the elements in the sentence that they link. Moreover, it is necessary to distinguish prepositions from conjunctions in both English and Vietnamese. Conjunctions are words that show an equality relationship, and prepositions represent a main-subordinate relationship. In English, prepositions also need to be distinguished from minor adverbs. Sub-adverbs differ from prepositions in terms of syntactic and grammatical features. 
In both English and Vietnamese sentences, a preposition always precedes the noun or pronoun that it governs to form a prepositional phrase (preposition). Prepositions in both languages can be used at the beginning of a complex sentence with a clause to indicate different meanings in translation, such as purpose, cause, and effect.

In conclusion, the study hopes to have partly contributed to the identification of the meaning of English prepositions in learning and translation. Therefore, the research paper hopes to be useful to English learners and individuals who are passionate about teaching aspects of the language, especially prepositions.

\section{Limitations}

The study is only a small contribution to the study of English prepositions by analyzing some transitional phenomena and briefly mentioning that a preposition can have many meanings and play different roles in the English language. In other words, there will be many phenomena that change the meaning of prepositions and the phenomenon of multiple meanings of each preposition that within the scope of this research paper will not be able to cover all of them.

According to Nguyen (2001), from the analysis of the prepositional systems of English and Vietnamese, we can see that the prepositional systems in both languages have diversity and rich activities. The English preposition system is considered difficult to use for Vietnamese learners because of the habit of translating the language directly from the mother tongue, and the meaning and usage of the preposition system are sometimes different from that of Vietnamese. Moreover, the differences in respective structures and spatial and temporal perception of the British and Vietnamese are often not the same.

The author also agrees with the point of view of Nguyen (2001), that teaching and learning English prepositions should not be separated from each other but should be taught and integrated into the process of grammar teaching and communication knowledge. In addition to the theory in class, learners need to practice in class to be able to remember the taught prepositions and use them correctly. First, they need to understand the nature of prepositions between English and Vietnamese, then gradually apply them through small exercises, then progress to the exercises of compounding sentences and completing sentences. In addition, the role of the mother tongue needs to go hand in hand with learning English. Secba (1979), in the book "On foreign language teaching methods," said: "Experience has shown that it is impossible to give up the mother tongue in the process of learning a foreign language, but it is impossible to remove the mother tongue from the students' minds obtainable" (213).

\section{Discussion}

In addition, the study suggests that in teaching translation, especially prepositions, teachers should pay attention to making learners understand that preposition translation should not be translated directly in their own language. They must rely on context and semantics in linguistics. Teachers also need to help learners limit the habit of translating everything into their native language, especially prepositions, because the case of a preposition with multiple meanings 
does occur. Furthermore, based on cultural differences and habits of using prepositions in different languages, teachers should also understand clearly so that they can help learners reduce mistakes when using prepositions. During the teaching process, the teacher should:

- Analyzing the phenomenon of meaning change of prepositions when translating from English to Vietnamese in translation so that learners can accurately translate the meaning of sentences.

- Analyzing the case of multiple meanings of prepositions in translation that, in addition to common meanings, can have other meanings in different contexts.

- Analyzing other roles of prepositions in sentences, which can be verbs or conjunctions.

\section{References}

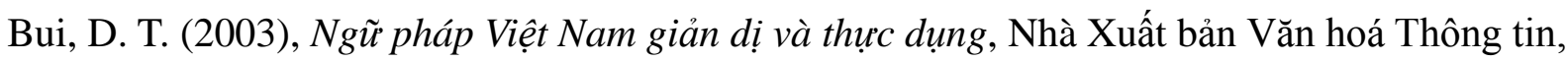
Hà Nội.

Collins, C. (Nguyễn Thành Yến dịch và chú giải) (2004), Giới tù tiếng Anh, Nhà Xuất bản Thành phố Hồ Chí Minh.

Cao, X. H. (1991), Tiếng Việt - sơ thảo ngũ pháp chức năng, Q1, Nhà Xuất bản Khoa học Xã hội, Hà Nội.

Cao, X. H. (2005), Ngũu pháp chức năng tiếng Việt, Q2, Nhà Xuất bản Giáo dục, Hà Nội.

Hutch, T. (2015) 150 Everyday Uses of Prepositions in English, Learning Express.

Lindstrormberg, S. (2010). English Prepositions Explained, Amsterdam: John Benjamins Publishing Company.

Nguyen, B. V., \& Ngo, T. C. T. (2021). Using the internet for self-study to improve translation for English-majored seniors at Van Lang University . International Journal of TESOL \& Education, 1(2), 110-147. Retrieved from http://ijte.org/index.php/journal/article/view/43

Nguyen, C. H. (2001), Nghiên cứu ngũ pháp và ngũ nghĩa của giới tù̀ tiếng Anh đối chiếu với tiếng Viẹt, Doctoral Thesis, University of Social Sciences and Humanities - Ho Chi Minh City National University.

Nguyen, H. P. (2010), Chức năng của giới tì̀ tiếng Việt xét trên bình diện ngũu pháp và ngũu nghĩa, Tạp chí Đại học Sư phạm Thành Phố Hồ Chí Minh.

Nguyen, K. T. (1963), Nghiên cúu về ngũu pháp tiếng Việt, Nhà Xuất bản Khoa học Xã hội, Hà Nội.

Nguyen, T. T. H. (2020), Giới tù định vị tiếng Anh (at, in, on) và các đơn vị tương đương trong tiếng Việt, Doctoral Thesis, University of Social Sciences and Humanities - Ho Chi Minh City National University. 
Nguyen, T. V. K. (2001), Nghiên cứu các nghĩa của giới tù “in” trong tiếng Anh và các nghĩa tuoong đuơng trong tiếng việt dưới góc độ ngôn ngũ học tri nhận, Mater thesis, University of Foreign Languages - Hanoi National University.

Nguyen, X. M. (2021). Strategies for Translating English Passive Sentences into Vietnamese. International Journal of TESOL \& Education, 2(1), 81-104. https://doi.org/10.54855/ijte22216

Phan, K. (1955), Việt ngũu nghiên cưu, Nhà Xuát bản Đà Nẵng, Đà Nẵng.

Secba (1979), On foreign language teaching methods

Tran, L. H. N. V. T. (2021). An Analysis of Negative Verbs' Equivalents in a Vietnamese Translation of 'The Call of the Wild'. International Journal of TESOL \& Education, 2(1), 105-116. https://doi.org/10.54855/ijte.22217

The Macmillan Company (1964), The Key to English Prepositions 1, Fourth Printing 1968, Collier-Macmillan International, Collier-Macmillan Limited, London, v.

Tran, Q. H. (2001). Nghiên cứu giới tù định vị theo hương ngũ dụng trên cú liệu tiếng Anh và tiếng Việt, Master Thesis, University of Social Sciences and Humanities - Ho Chi Minh City National University.

Tran, T. K. (1940), Việt Nam văn phạm, Sài Gòn.

Tran, V. D. (1997). Cách dùng giới tùu Anh ngũu, Nhà Xuất bản Thành phố Hồ Chí Minh.

Yates, J. (2020). Barron's ESL Proficiency Series: Prepositions, Kaplan, Inc., Barron's Educational Series, 2020 Edition, 750 Third Avenue, New York, NY 10017.

\section{Biodata}

As an excellent student at Sai Gon University, Phat Dinh Dac has won a championship in an annual contest "The Winner" and conducted a scientific research at the university level. He will be able to get more achievements when he has been exposed to scholarly atmosphere like the one created by this Conference. 